\title{
Prenatal diagnosis of a rare case of iniencephaly apertus
}

\author{
Mahy Mohsen', Ahmed El Sheikhah"1, Lamees Mohamed", Sief El-Eslam A. Ali², \\ Armia Michael ${ }^{2}$, Ahmad A. Radwan ${ }^{3}$, Shymaa S. Ali ${ }^{2}$, Ahmed M. Abbas ${ }^{2 *}$
}

${ }^{1}$ Fetal Medicine Unit, Cairo University, Cairo, Egypt

${ }^{2}$ Department of Obstetrics and Gynecology, Faculty of Medicine, Assiut University, Egypt

${ }^{3}$ Faculty of Medicine, Assiut University, Egypt

Received: 27 January 2018

Accepted: 28 February 2018

\section{*Correspondence:}

Dr. Ahmed M. Abbas,

E-mail: bmr90@hotmail.com

Copyright: (C) the author(s), publisher and licensee Medip Academy. This is an open-access article distributed under the terms of the Creative Commons Attribution Non-Commercial License, which permits unrestricted non-commercial use, distribution, and reproduction in any medium, provided the original work is properly cited.

\section{ABSTRACT}

Iniencephaly is a rare neural tube defect that was firstly reported by Saint-Hilaire in 1836. Its incidence ranges from 0.1 to 10 in 10,000 deliveries with higher incidence in females. The most common features present iniencephaly are bifida at the cervical region, defect in the occipital bone and retroflexion of the head on the cervical spine. Here we report a case of a 24 years old second gravida with a history of consanguinity. She presented with a malformed fetus at 22 weeks gestation diagnosed by detailed ultrasonographic anatomy scan as iniencephaly apparatus. Termination of pregnancy was performed vaginally through medical induction by prostaglandins.

Keywords: Congenital malformations, Iniencephaly, Neural tube defect, Prenatal

\section{INTRODUCTION}

Iniencephaly is one of the uncommon neural tube defects (NTD) that was firstly reported by Saint-Hilaire in $1836 .{ }^{1}$ The word inion is a Greek word means the occiput or the nape of the neck. ${ }^{2}$ Its incidence ranges from 0.1 to 10 in 10,000 being more common in female babies. ${ }^{3}$

Three common features characterize this disorder: spina bifida at the cervical region, defect in the occipital bone and retroflexion of the head on the cervical spine. ${ }^{4}$ There are two main types of iniencephaly.

One of them is the iniencephaly apertus which is the most severe form involving the development of an encephalocele. The other one with absent encephalocele is called iniencephaly clausus. ${ }^{5}$ Cardiovascular disorders, diaphragmatic hernias, and gastrointestinal malformations are other additional defects seen in these cases. $^{6}$
Iniencephaly is not a genetic disease; however, the exact etiology for its occurrence is still unknown. Certain factors previously published in the literature could be associated with an increased risk of development. Chromosomal abnormalities as trisomy 18 , trisomy 13 , and monosomy $\mathrm{X}$ have been linked to iniencephaly. ${ }^{7}$ Women with low socioeconomic status and poor nutrition especially folic acid deficiency and/or hyperhomocysteinemia have shown to be at larger risk. ${ }^{7}$ Induction of ovulation by clomiphene citrate has also been found to be associated with iniencephaly. ${ }^{8}$ Some studies reported that maternal obesity could increase the risk of iniencephaly by 1.7 fold while severe obesity increases the risk by over 3 fold. ${ }^{9}$

Previous delivery of iniencephalic fetus is associated with $1-5 \%$ risk of recurrence in subsequent pregnancies. ${ }^{5}$ Herein, we present a rare case of iniencephaly apertusaccidentally diagnosed at 22 weeks gestation in apparently healthy pregnant woman. 


\section{CASE REPORT}

A 24-year-old gravida 2 para $1+0$ pregnant at 22 weeks gestation referred from primary maternal care unit in her village for possibility of congenital deformities affecting the CNS. She was presented at our tertiary fetal medicine unit for detailed anatomy scan of her fetus. She was currently married for 3 years from her cousin that resembles a history of strong consanguinity. She was not known to be diabetic or hypertensive.

The patient had a history of vaginal delivery of single healthy full term male fetus with no congenital anomalies two years ago. She didn't receive any contraception after her first pregnancy. She started taking $0.4 \mathrm{mg}$ folic acid tablets daily from the beginning of her pregnancy till the end of the first trimester. She had no family history of any congenital anomalies.

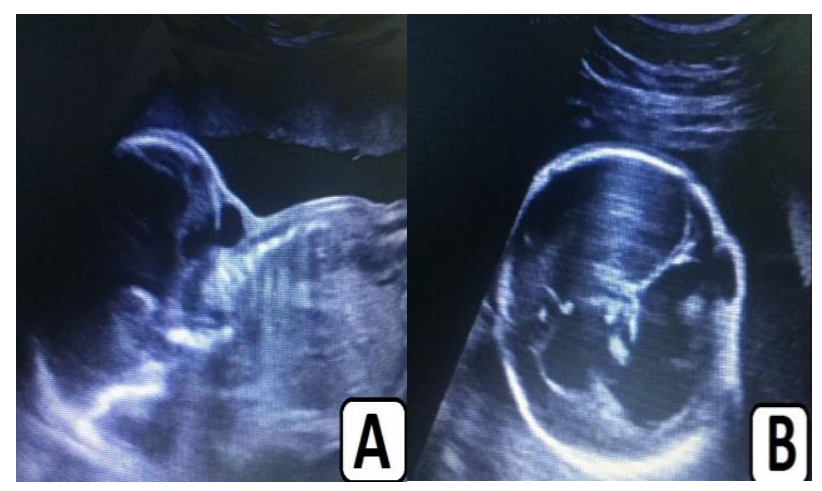

Figure 1: ultrasound evaluation of the fetus at 22 weeks gestation showing the following abnormalities-

A: small posterior encephalocele, B: Bilateral ventriculomegaly.

Ultrasound evaluation reported a single female fetus with average biometry 22 weeks gestation. The fetus showed small posterior encephalocele (Figure 1A), bilateral ventriculomegaly (Figure 1B), absent cervical vertebra with star gazing appearance (Figure 2C) and associated diaphragmatic hernia (Figure 2D).

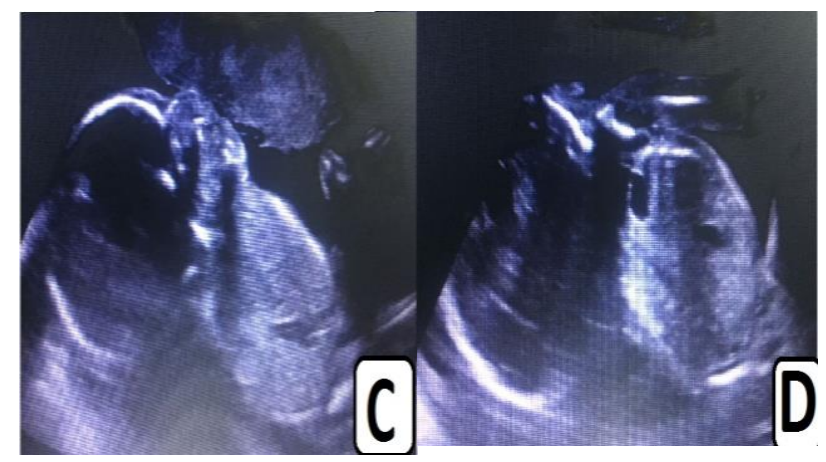

Figure 2: Ultrasound evaluation of the fetus at 22 weeks gestation showing the following abnormalitiesC: absent cervical vertebra with star gazing appearance and D: diaphragmatic hernia.
Counseling of the patient about the prognosis of the fetus condition, she requested termination of pregnancy by medical induction. After taking an informed written consent from the patient and her husband, medical induction was done using vaginal misoprostol $50 \mathrm{mcg}$ every 6 hours until delivery occurred. The family did not allow autopsy of the baby because of religious reasons.

\section{DISCUSSION}

Closure of the neural tube mostly happen around day 28 of pregnancy and failure of its closure may lead to a defect graded from a small meningocele to lifethreatening conditions. Examples of NTDs are anencephaly, iniencephaly, craniorachischisis, meningomyelocele, meningocele, and encephalocele. ${ }^{10}$ Iniencephaly is nearly represents about $1 \%$ of all fetal abnormalities, with an incidence rate ranging between 0.1 and 10 in 10,000 deliveries. ${ }^{11}$

As the definite pathogenesis is still unknown, there are many theories for explanation of this rare condition. Erdincler et al attributed this anomaly to presence of a defect in the occipital bone with rachischisis of the posterior vertebral arches that leads to herniation of neural tissue through the bone defect during pregnancy. ${ }^{4}$

Iniencephaly is seen in families with a history of NTDs and the recurrence risk is up to $5 \% 5$, however in our case there was no family history of any congenital anomalies in both partners. The important features of iniencephaly are abnormalities of the occipital bones, leading to a larger foramen magnum, absence of cervico-thoracic regions of the vertebral column associated with an abnormal fusion of the present vertebrae and defective fusion of the vertebral arches and bodies, shortening of the spinal column as a result of marked lordosis and hyperextension of the malformed spine, upward-directed face and star-gazing appearance. ${ }^{12}$

Additionally, it may be associated with other congenital anomalies such as anencephaly, encephalocele, meningomyelocele, hydrocephalus, Dandy-Walker malformation, holoprosencephaly, omphalocele, congenital diaphragmatic hernia, hydronephrosis, polycystic kidneys, cardiac defects, caudal regression sequence, arthrogryposis, clubfoot, single umbilical artery, and gastrointestinal atresia. ${ }^{13}$ The most common associated anomalies previously reported are spina bifida (74\%), diaphragmatic hernia (37\%), adrenal hypoplasia (37\%) and club foot (32\%). ${ }^{14}$ The current reported case was associated with encephalocele and congenital diaphragmatic hernia.

Prenatal diagnosis of iniencephaly is feasible by either ultrasonography or MRI. The fetus is typically show star gazing appearance on ultrasonography. Detailed anatomical scan of the fetal CNS and spine can reveal all the aforementioned deformities. Iniencephaly can be diagnosed easily in the first trimester of pregnancy. 
Marton et al suggested that iniencephaly could be suspected if a short neck, short crown-rump length, severely fixed retroflexed head and a cervical myelocele are present at 10 th week of gestation. ${ }^{15}$

Regarding primary prevention of the condition, pregnant women are advised to take folic acid supplements that reduce the risk of iniencephaly by nearly $70 \%$. Additionally, avoidance of any medications associated with increase risk of NTDs in early pregnancy as antiepileptic drugs, diuretics, and antihistamines. ${ }^{16}$

Iniencephaly has a very poor prognosis and both types are incompatible with life. Most of cases are ending in spontaneous miscarriage or stillbirth. There are only six cases reported in the literature of iniencephaly with relatively long-term survival. ${ }^{17}$ No standard treatment exists for this condition as most of newborns rarely survive after delivery. In cases associated with minor malformations, cervical deformities could be improved by neurosurgical intervention. ${ }^{5}$ Termination of pregnancy should be offered after counseling once the condition is diagnosed antenatally. Since it has a high recurrence rate, women should be counseled for folic acid supplementation even before next pregnancies.

\section{CONCLUSION}

In conclusion, iniencephaly is an extremely rare NTD with a lethal outcome. Prenatal diagnosis by ultrasonography is relatively easy due to presence of multiple severe anomalies. Termination of pregnancy offer is important to reduce maternal risks.

Funding: No funding sources Conflict of interest: None declared

Ethical approval: The study was approved by the Institutional Ethics Committee

\section{REFERENCES}

1. Hilaire IG. Iniencephalus. In: Bailliere J, ed. History of the Anomalies of the Organization, Paris, 1836;2:308-10.

2. Hemal U, Solanki RS, Varsheney A, Baliga S. Prenatal diagnosis of iniencephaly on ultrasound. Indian J Radiol Imaging. 2004;14(3):265-6.

3. Romero R, Pilu G, Jeanty P, Ghidini A, Hobbins J. Iniencephaly, in Prenatal Diagnosis of Congenital Anomalies, $3^{\text {rd }}$ ed. Appleton \& Lange, Norwalk, Conn, USA, 1988.65

4. Erdinçler P, Kaynar MY, Canbaz B, Koçer N, Kuday C, Ciplak N. Iniencephaly: Neuroradiological and surgical features. Case report and review of the literature. J Neurosurg. 1998;89(2):317-20..

5. Pungavkar SA, Sainani NI, Karnik AS, Mohanty PH, Lawande MA, Patkar DP et al., Antenatal diagnosis of iniencephaly: Sonographic and MR correlation: A case report. Korean J Radiol. 2007;8(4):351-5.

6. Tugrul S, Uludoğan M, Pekin O, Uslu H, Celik C, Ersan F. Iniencephaly: Prenatal diagnosis with postmortem findings. J Obstet Gynaecol Res. 2007; 33(4):566-9.

7. Kulkarni PR, Rao RV, Alur MB, Joshi SK. Iniencephaly clausus: A case report with review of literature. J Pediatr Neurosci. 2011;6(2):121.

8. Bhambhani V, George S. Association of Clomiphene with Iniencephaly. Indian Pediatr. 2004; 41(5):517.

9. Rasmussen SA, Chu SY, Kim SY, Schmid CH, Lau J. Maternal obesity and risk of neural tube defects: A metaanalysis. Am J Obstet Gynecol. 2008; 198(6):611-9.

10. Mórocz I, Szeifert GT, Molnár P, Tóth Z, Csécsei K, Papp Z. Prenatal diagnosis and pathoanatomy of iniencephaly. Clin Genet. 1986;30(2):81-6.

11. Nyberg DA, McGahan JP, Pretorius DH, Pilu G. Diagnostic imaging of fetal anomalies. $1^{\text {st }}$ ed. Lippincott Williams \& Wilkins. Philadelphia: 2003:315-316

12. Woodward PJ, Kennedy A, Sohaey R, Byrne J, Oh K, Puchalsk M. Diagnostic Imaging: Obstetrics. $1^{\text {st }}$ ed.: AMIR SYS Inc, Salt Lake City 2005:10-4.

13. Sahid S, Sepulveda W, Dezerega V, Gutierrez J, Rodriguez L, Corral E. Iniencephaly: prenatal diagnosis and management. Prenat Diagn. 2000; 20(3):202-5.

14. Balci S, Aypar E, Altinok G, Boduroğlu K, Beksaç MS. Prenatal diagnosis in three cases of iniencephaly with unusual postmortem findings. Prenat Diagn. 2001;21(7):558-62.

15. Marton T, Tanko A, Mezei G, Papp Z. Diagnosis of an unusual form of iniencephaly in the first trimester of pregnancy. Ultrasound Obstet Gynecol. 2001; 18(5):549-51.

16. NINDS Iniencephaly Information Page. National Institute of Neurological Disorders and Stroke (NINDS). NINDS, 13 Feb. 2007.

17. Aytar MH, Doğulu F, Cemil B, Ergün E, Kurt G, Baykaner K. Iniencephaly and long-term survival: A rare case report. Childs Nerv Syst. 2007; 23(6):71921.

Cite this article as: Mohsen M, Sheikhah AE, Mohamed L, Ali SA, Michael A, Radwan A et al. Prenatal diagnosis of a rare case of iniencephaly apertus. Int J Reprod Contracept Obstet Gynecol 2018;7:1635-7. 